\title{
水熱合成法により生成した $\mathrm{CeO}_{2}$ ナノ粒子の構造・形状解析
}

\author{
九州大学大学院工学研究院 金子 賢 治 北脇高太郎 \\ 日本エフイー・アイ株式会社 伊野家浩司 \\ ケンブリッジ大学材料科学工学部 A. B. Hungria P. A. Midgley
} 東北大学多元物質科学研究所 張 静大原 智阿尻雅文
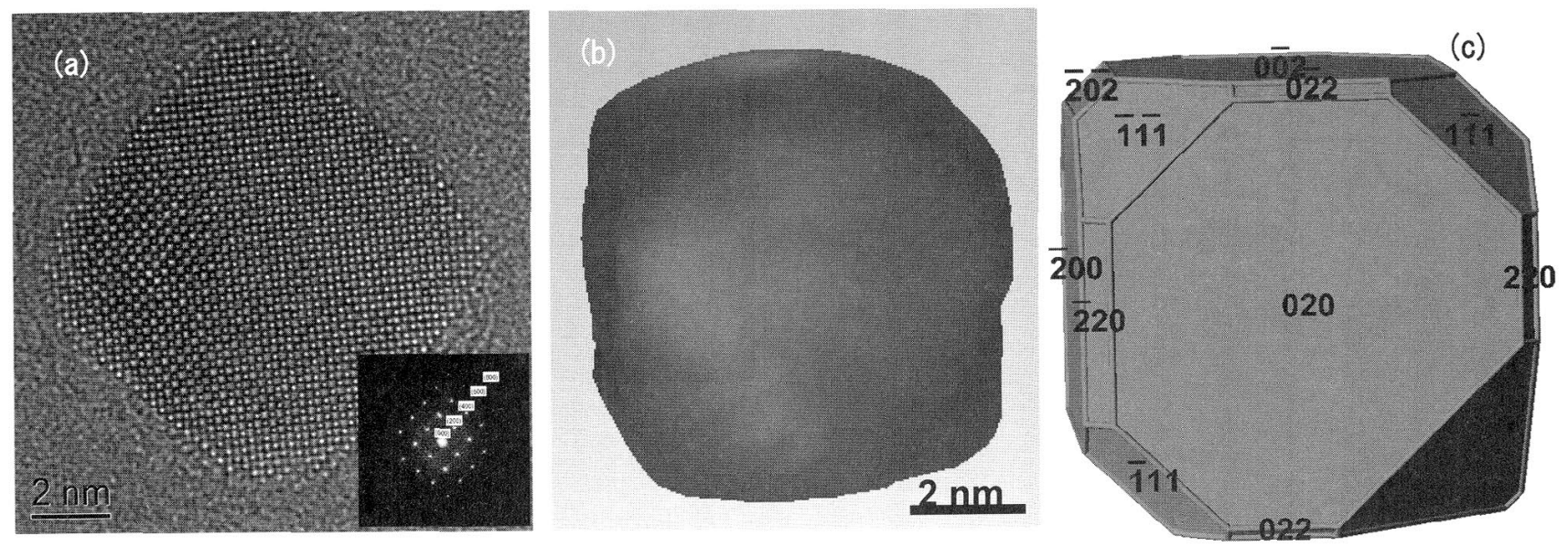

Fig. 1 (a) $\mathrm{CeO}_{2}$ ナノ粒子の高分解能像 $[100]$ 入射, (b) $\mathrm{CeO}_{2}$ ナノ粒子の 3 次元再構築像, (c) モデル図.

近年，固体酸化物形燃料電池 (Solid oxide fuel cell: SOFC)が注目を集めている。その理由としては， SOFCの高いエネルギー変換効率と環境適合性などが めげられ，今世紀の新しい低公害の電力発電源として 注目されている.SOFCの実用化のため，酸素イオン 導電性酸化物として固体電解質に利用されている酸化 セリウム $\left(\mathrm{CeO}_{2}\right)$ に関心が寄せられてきている. $\mathrm{CeO}_{2}$ はこの他にも，様々な触媒として用いられており，電 極触媒やメタノールから水素を直接生成させる時の触 媒としても利用されている(1)。触媒活性を向上させる 観点加，高い表面積を持ち，高い触媒活性を有与る $\{100\}$ を持つ $\mathrm{CeO}_{2}$ ナノ粒子を作製することが重要と なる、実際には $\mathrm{CeO}_{2}$ は蛍石構造をとるため，正八面 体構造をとりやすく, $\{100\}$ のみ加らなる立方体の $\mathrm{CeO}_{2}$ ナノ粒子を作製することは困難である(2).

電子線トモグラフィ $(\mathrm{TEM}-\mathrm{CT})$ 法では, 傾斜像寺 取得している時に多くの TEM パラメータ(イメージ シフトや試料傾斜など)が制御されている。TEM-CT のデータ取得は電子線に対して単軸に試料を傾斜させ て行った。試料傾斜像は HAADF-STEM 像を用い一 $70^{\circ}$ から $74^{\circ}$ をで $2^{\circ}$ ステップで傾斜し撮影を行い, 計 73枚の写真を取得した。高角度に散乱された電子は
HAADF 検出器で集められ，その信号強度は抢抢よ そ $Z^{2}$ に比例する( $\mathrm{Z}$ は原子番号)，Zコントラスト法 を用いたTEM-CT は (多) 結晶材料の研究を行う上 で, 傾斜による回折コントラストの発生を低減するこ とが可能であることから，非常に有効である(3).

水熱合成法により生成されたコロイド状の $\mathrm{CeO}_{2}$ ナ ノ結晶を高分解能観察と TEM-CT により解析を行っ た。Fig. 1(a)に示すように，[100]入射の高分解能像 観察の結果から，それぞれの面が $\{200\} に$ に囲まれてい ることが判明した。また，Fig. 1(b)，(c)に示すよう に TEM-CTにより $\mathrm{CeO}_{2}$ ナノ結晶は $\{200\}$ を多く有 した立方体の形状をして抢り，八面体の面に形成され る\{111\}が隅に，十二面体の面に形成される $\{220\}$ が エッジの所に存在することが判明した。

\section{文献}

(1) L. Mo, X. Zheng and C-T. Yeh: Chem. Commun., (2004), 1426.

(2) T. X. T. Sayle, S. C. Parker and C. R. A. Catlow: Surf. Sci., 316 (1994), 329.

(3) P. A. Midgley, M. Weyland: U1tramicroscopy, 96 (2003), 413. (2007年 7 月23日受理)

Structural and Morphological Characterization of Cerium Oxide Nanocrystals Prepared by Hydrothermal Synthesis; Kenji Kaneko*, Kotarou Kitawaki*, Koji Inoke**, Ava B. Hungria***, Paul A. Midgley***, Jing Zhang****, Satoshi Ohara****, Tadafumi Adschiri*****Department of Material Science and Engineering, Kyushu University, Fukuoka, **FEI Company Japan Ltd., Tokyo, ***Department of Materials Science and Metallurgy, University of Cambridge, Cambridge, UK, ****IMRAM, Tohoku University, Sendai, Japan)

Method: Cerium oxide was prepared by mixing $100 \mathrm{ml}$ of $0.1 \mathrm{M} \mathrm{Ce}\left(\mathrm{NO}_{3}\right)_{3}$ solution with $100 \mathrm{ml}$ of $0.3 \mathrm{M} \mathrm{NaOH}$ and stirred for about $6 \mathrm{~h}$ TEM-utilized: FEI TITAN 80-300 (300 kV) and FEI TECNAI-20 $(200 \mathrm{kV})$. 